\title{
LET HE WHO IS WITHOUT SIN CAST THE FIRST STONE: FOREIGN DIRECT INVESTMENT AND NATIONAL SECURITY REGULATION IN CHINA
}

\author{
Stephen Sothmann*
}

\section{INTRODUCTION}

On August 31, 2007, the National People's Congress (NPC) of the People's Republic of China passed the final draft of a new antitrust law that had been in development for several years. ${ }^{1}$ Before the new law, China did not have one unified system of antitrust regulation. There were several anticompetitive rules codified in various forms throughout Chinese law, but those provisions were scarce and scattered over many areas of regulation. ${ }^{2}$ As early as 1988 , the Chinese government decided that a uniform set of competition laws was necessary in order to preserve the developing free market from what was perceived to be unfair competitive practices. ${ }^{3}$ The need for one system of regulation became increasingly important to China's leadership as its economy escalated in the late 1990s and the amount of Foreign Direct Investment (FDI) in the country increased dramatically. ${ }^{4}$ Many Chinese citizens and government officials were concerned that multi-national corporations would enter the market, acquire many of China's profitable companies, and deny the Chinese people the benefits of their booming economy. In response to this growing need, the NPC developed a series of laws that would culminate in the passage of the August 31, 2007 antitrust legislation.

A few provisions of the new law have caused concern in the international business community. ${ }^{6}$ Among the primary concerns are the large number of exemptions for monopolistic behavior in "critical" economic sectors, potential

* J.D. expected 2009. I would like to thank my editors, Jenny Prinz and Matt Morgan, for all of their help, as well as Professor Robert Lancaster for his guidance in the development of this Note. I would also like to thank my parents for all of their support during this process.

1. At the time of writing no official translation of the law existed. For the purposes of comparison, this unofficial translation of the law was used: Anti-Monopoly Law of the People's Republic of China (2007), available at http://www.antitrustchina.com/default.asp?id=218 (click on "Full Bi-lingual Version," a login username and password is needed to access the material) [hereinafter Anti-Monopoly Law].

2. H. Stephen Harris, Jr., The Making of an Antitrust Law: The Pending Anti-monopoly Law of the People's Republic of China, 7 CHI. J. INT'L L. 169, 175-76 (2006).

3. Id. at 174-76.

4. MSN Encarta - China, http://encarta.msn.com/encyclopedia_761573055/China.html\#p7 (last visited Nov. 30, 2008).

5. Id.

6. See The Law Offices of Clifford Chance, Chinese Anti-trust: Let the Games Begin (Aug. 2007), available at http://www.cliffordchance.com/expertise/publications/details.aspx?FilterName= @URL\&LangID=UK\& contentitemid=12590. 
abuse of administrative power by regional governments, the applicability of the new law to State Owned Enterprises (SOEs), and the ability of government bureaucrats to manipulate the law in order to achieve economic protectionism. ${ }^{7}$ In particular, Article 31 of the legislation has sparked considerable debate among foreign observers because it allows the Chinese government to deny foreign mergers or acquisitions based on "national security interests." Article 31 states:

Where a foreign investor participates in the concentration of business operators by merging or acquiring a domestic enterprise or by any other means, and national security is involved, besides the examination on the concentration of business operators in accordance with the Law, the examination on national security shall also be conducted according to the relevant provisions of the State. ${ }^{9}$

Under this Article, a foreign party attempting to acquire or merge with a Chinese domestic company will be subject to both an economic antitrust review and an additional review based on national security concerns. If the government deems the foreign merger or acquisition dangerous to the national security of China, the transaction will be denied. The international community is especially concerned that the term "national security" has not been defined anywhere in the legislation, nor has the NPC given any specific instructions as to what types of industries will be affected by this rule. ${ }^{10}$ This added level of scrutiny could give the Chinese government the ability to deny foreigners the opportunity to enter the lucrative Chinese market in favor of domestic counterparts. ${ }^{11}$ There is concern that such protectionist actions would lead to a form of legalized isolationism in the burgeoning economy.

Given China's well-documented closed-door policies of the past, ${ }^{12}$ it is understandable that the international community would question any new laws that allow government officials to effectively deny foreign investment. This is especially true considering the number of SOEs that still dominate many sectors of the country's economy and hold considerable sway in political decisionmaking. ${ }^{13}$ However, it is the purpose of this Note to prove that the international

7. Id.

8. See Anti-Monopoly Law, supra note 1, at art. 31 .

9. Id.

10. Id.

11. Id.

12. See generally Joel R. Samuels, "Tain't What You Do": Effect of China's Proposed Anti-Monopoly Law on State Owned Enterprises, 26 PENN ST. INT'L L. REV. 169 (2007) (discussing that China's economy was closed off to foreign investment for many years following the communist revolution of 1949 and remained closed until the open door policies of Deng Xiaoping in the 1970 s led to increased foreign investment and economic growth in the 1980 s and 90s).

13. Id. 
uproar over the legislation may be unfounded considering the present political and economic landscape of international trade.

The critical consideration is that several nations, including many western nations, have some form of restriction on international mergers and acquisitions in industries that are considered integral to "national security." 14 Patterns have emerged as to the types of industries that governments usually choose to protect, such as the energy or weaponry sectors of a domestic economy, but many nations also restrict foreign investment outside of these industries. ${ }^{15}$

Most governments also have some form of statutory review process for foreign mergers and acquisitions in the domestic economy that look at a myriad of issues, including national security. ${ }^{16}$ Furthermore, many international free trade agreements, including the World Trade Organization (WTO), Association of Southeast Asian Nations (ASEAN), European Union (EU) and the North American Free Trade Agreement (NAFTA), allow signatory nations the right to deny foreign investment in areas of the economy deemed integral to the national security interests of that nation. ${ }^{17}$ Even the United States, traditionally the most open and free market in the world, allows for governmental review of foreign takeovers based on national security interests. ${ }^{18}$ In fact, the level of governmental oversight for foreign mergers and acquisitions in the United States has been expanding in recent years as a result of post-9/11 national security legislation. ${ }^{19}$ Considering these accepted international practices for economic policy and national security review, the Chinese antitrust law is, on its face, no different than the others in terms of the standards it sets for reviewing foreign mergers and acquisitions in its domestic economy. ${ }^{20}$

The international community's reaction to Article 31 of the Chinese antitrust law is largely based on concerns with China's economic past, not on the political and economic realities of the present. As stated above, many nations reserve the right to deny foreign mergers or acquisitions based on national security concerns. This exception to free trade has been a part of the global economy since the earliest free trade agreements. Even the United States uses national security concerns in order to deny foreign takeovers. It is a global trend that has moved towards economic protectionism in "crown jewel" industries within each nation.

This Note will detail that the new Chinese law is in accordance with

14. Gaurav Sud, Note, From Fretting Takeovers to Vetting CFIUS: Finding a Balance in U.S. Policy Regarding Foreign Acquisitions of Domestic Assets, 39 VAND. J. TRANSNAT'L L. 1303, 1312 (2006).

15. See infra Part IV.

16. See infra Part IV.

17. See infra Part III.

18. Joseph Mamounas, Controlling Foreign Ownership of U.S. Strategic Assets: The Challenge of Maintaining National Security in a Globalized and Oil Dependant World, 13 L.\& Bus ReV. AM. 381, 388 (2007).

19. Id. at 381 .

20. See supra the analysis that follows. 
international standards in terms of foreign merger and acquisition review and should not be isolated by the international community. Part I of this Note examines the international reaction to China's new antitrust law. Part II identifies the industries usually affected by national security exceptions to free trade agreements, specifically, the industries that have previously been affected in China. Part III discusses the legality of those exceptions under current free trade agreements, including the WTO, ASEAN, EU and NAFTA agreements. Part IV shows examples of nations choosing to isolate and protect specific domestic industries based on notions of national security. Part V discusses the history of foreign investment review in the United States and the shift towards economic protectionism in a post-9/11 environment. Finally, Part VI provides recommendations for various parties so that Article 31 of the Chinese antitrust law might assimilate smoothly into the world economy.

\section{INTERNATIONAL REACTION TO THE CHINESE ANTITRUST LAW}

Both before and after the passage of China's new antitrust legislation, foreign press documented the international business community's apprehension that the law might cause China to slip into economic isolationism. Although several international organizations and western nations have contributed to the development of the new law, ${ }^{21}$ many still express concern that the law will give Chinese officials the power to arbitrarily reject foreign investment in domestic assets. "Some fear the forthcoming antimonopolization law, however reasonable its wording, will be used to discriminate against foreign companies or curb their intellectual-property rights. ${ }^{\text {23 }}$ The second level of antitrust review under Article 31, the national security review, specifically causes concern among potential foreign investors. "It is not clear how such a review will be applied, especially given that 'public interest' [national security] is not defined in the law. This concern is further underlined by the law's emphasis on safeguarding certain state-dominated industry sectors. ${ }^{24}$ These concerns have led many foreigners to conclude that the new Chinese law "appears to open the door for regulators to target [foreign companies], while strengthening the hand of state-owned monopolies."25

The international concern over the resurgence of an economically isolated China may be overstated, but the business community's reaction to the new law is not completely without merit. Some of the NPC's recent actions concerning foreign investment have shown an increase in prolonged investigations, or

21. See generally Harris, supra note 2.

22. Roger Parloff, Sony's China Problem: Will a Lawsuit Against Sony in China Set a Scary Precedent?, FORTUNE (Feb. 22, 2007), available at http://money.cnn.com/ magazines/fortune/fortune_archive/2007/03/05/8401275/index.htm.

23. $I d$.

24. Rowan Callick, China Anti-monopoly Law Concerns, The Dally Telegraph (Sept. 3 , 2007), available at $\mathrm{http}: / / \mathrm{www}$. news.com.au/business/story/0,27753,22350658-462,00.html.

25. Id. 
outright denials, of foreign mergers and acquisitions based on national security issues. ${ }^{26}$ Foreign press has been quick to identify and sensationalize examples of these slowdowns, even if they were later approved. For example, in his article, Bradsher describes current Chinese foreign investment regulations by offering explanatory anecdotes: "even a French purchase of a Chinese cookware company was delayed this year for a national security review, although the Commerce Ministry eventually gave its approval."27 The description of China's economic landscape for foreign investors has been less than favorable for the governmental regulators. However, anecdotes aside, there has been a marked increase in the amount of foreign companies experiencing administrative hang-ups in their attempts to merge or acquire a domestic Chinese company. ${ }^{28}$ The percentage of foreign investment in China actually decreased by $8.5 \%$ in 2006 , due in large part to the administrative obstacles companies endured in order to enter the Chinese market. ${ }^{29}$

One recent high-profile example of this burdensome endurance is Carlyle Group's attempt to acquire the Chinese manufacturing firm Xugong Machinery. ${ }^{30}$ In November of 2005, Carlyle Group extended an initial bid of $\$ 375$ million for an $85 \%$ ownership interest in the domestic Chinese company. ${ }^{31}$ The company designed and manufactured a wide range of engineering machinery, including cranes, road rollers, earth scrapers, concrete machines and their basic parts and components. The deal was significantly delayed by the Chinese government's foreign acquisitions review process and the delay eventually led to Carlyle restructuring its bid to quicken the process. ${ }^{32}$ Instead of the $85 \%$ interest it had originally sought, Carlyle Group revised its agreement with Xugong to a $\$ 230$ million sale worth $50 \%$ of the company, with the remaining $50 \%$ interest reserved for the regional government overseeing the acquisition. ${ }^{33}$

Due to these types of situations, many foreign investors believe the Chinese government is applying the national security review to a much broader range of companies than other free trade nations. ${ }^{34}$ Critics believe that these companies "would not be seen as security risks in the United States." 35 In most cases, the Chinese government's reviews have slowed the process of foreign investment, but they have not denied many companies the opportunity to enter

26. Keith Bradsher, China Casts Wary Eye on Takeovers, INT'L HERALD TrIB., Aug. 27, 2007, at Business, available at http://www.iht.com/articles/2007/08/27/business/monopoly.php.

27. Id.

28. Eileen Francis Schneider, Note, Be Careful What You Wish For: China's Protectionist Regulations of Foreign Direct Investment Implemented in the Months Before Completing WTO Accession, 2 BroOK. J. CORP. FIN. \& COM. L. 267, 270 (2007).

29. Id. at 276.

30. Id. at 275 .

31. Id.

32. Id.

33. Id. at 255.

34. Bradsher, supra note 26.

35. Id. 
the market.

However, a few foreign companies have been outright denied in their attempt to acquire a significant stake in a domestic Chinese entity. ${ }^{36}$ For example, on August 29, 2007, the China Securities Regulatory Commission rejected Goldman Sachs' $\$ 91$ million bid for a $10.7 \%$ stake in home appliance manufacturer Midea Electric for national security reasons, but did not disclose why the purchase would be a danger to national security. ${ }^{37}$ Similarly, Citigroup ran into problems in 2006 when it tried to buy a 30\% stake in China's Shandong Chenming Paper Holdings Ltd, a paper producing company. ${ }^{38}$

Furthermore, government officials have publicly identified several nondefense industries that they consider worthy of protection from foreign interference. $^{39}$ Examples of these industries include retailers, soybean processors, automakers, bearings manufacturers, cement producers, telecom agencies, and steel producers. ${ }^{40}$ Companies in these industries were able to successfully persuade the government that they needed protection from foreign competitors due to their strategic importance in the domestic economy. ${ }^{41}$ The governmental regulators have been quick to deny foreign investment in these sectors in favor of domestic enterprises. ${ }^{42}$ This has sparked concern among foreign investors that the list of protected industries will continue to expand as Article 31 of the new antitrust law is applied.

Some foreign investors are not apprehensive of the law itself, but are instead concerned with how the law will be used by officials in Chinese regulatory agencies. ${ }^{43}$ "A major concern is how the law will be implemented. The administrative rank of the new [antitrust regulatory] agency and its human and financial resources will be crucial. Lack of administrative and political influence, inadequate funding, and unqualified personnel will make impartial and effective enforcement impossible." ${ }^{44}$ It is difficult to assess how the law will be enforced in its early stages of implementation. "Legal analysts [say] the effect of the law [will] not be known until the government [begins] enforcing it." 45 For the next few years, "[f]oreign companies will closely scrutinize [the law's] implementation for signs that it is being used unfairly to prevent foreign takeovers ....,46

36. ECONOMIST INTELLIGENCE UNIT, China Regulations: Anti-monopoly Law Passed with Provisions for Foreign Business, Sept. 12, 2007, http://www.eiu.com.

37. Id.

38. Schneider, supra note 28 , at 270.

39. Id. at 277.

40. Id. at 274 .

41. Id.

42. Id.

43. Mark Williams, Wal-Mart in China: Will the Regulatory System Ensnare the American Leviathan?, 39 CONN. L. REV. 1361, 1380 (2007).

44. Id.

45. Peter Spiegel, Beijing Approves Ban on Some Monopolies, L.A. TrMES, Aug. 31, 2007, at Business, available at http://articles.latimes.com/2007/aug/31/business/fi-china31.

46. Id. 
Despite these indications, Chinese officials, through state-run media outlets, have attempted to ease the international concern by consistently proclaiming that the national security provision of the antitrust law will be enforced sparingly and in accordance with international standards. ${ }^{47}$ "The Antitrust Law aims to maintain the security of China's economic system, the same as relative to antitrust laws in other countries. .. . The Antitrust Law governs all social economic entities not just exclusively to foreign enterprises." 48 Furthermore, they state, "checks on mergers of foreign and domestic firms are practiced by many countries." 49 Yet proponents of an economically isolated China still have a voice in the state-run media outlets. For example, Zhang Jiachun, chairman of the East Group, believed that foreign-funded joint ventures were encroaching on the domestic retail sector and was quoted by the state-run media asking, "Who should control the lifeline of China's economy?",50

Judging by the sheer number of news articles expressing concern with the heightened level of review against foreign investment, the international business community does not believe that the Chinese government will implement the antitrust law fairly and evenly. Considering the amount of media coverage the Carlyle Group deal received, along with other blocked or stalled acquisitions in China, foreign investors are understandably worried that too many international companies are arbitrarily being denied entrance into the Chinese economy. But not every international corporation looking to operate in China should be concerned with the new law. There seem to be many economic sectors that are inherently immune to national security reviews.

\section{GENERALLY ACCEPTED DEFINITION OF "NATIONAL SECURITY" AND INDUSTRIES AFFECTED}

The international concern over China's new antitrust law arises directly from the lack of a clear definition for "national security" in Article 31. ${ }^{51}$ This lack of a clear definition has led many international observers, including the press and foreign investors, to conclude that Chinese officials will inevitably use the law to deny foreign investment in any industry they see fit. ${ }^{52}$ Without a clear definition for national security, the law can theoretically be applied to any

47. Alex Xu, Experts: No Need to Panic on Antitrust Law, CHINA.ORG.CN, May 9, 2003, http://www.china.org.cn/archive/2003-05/09/content_1064211.htm (last visited Nov. 30, 2008).

48. Id.

49. Harry L. Clark \& Lisa W. Wang, Foreign Investment and National Security, 35 CHINA Bus. REv. 1 (2008), available at http://www.deweyleboeuf.com/files/News/5020bb98-67184337-97a6-64667f03834d/Presentation/NewsAttachment/a3420492-97fd-4f45-9b4b$6900 \mathrm{e} 36248 \mathrm{eb} /$ Clark.pdf.

50. Xu, supra note 47.

51. Anti-Monopoly Law, supra note 1, at art. 31 (providing no specific definition of "national security").

52. See supra Part I for discussion about the international reaction to the new antitrust law. 
industry the government wishes to insulate from international competition. However, it is possible to create a list of the industries that will most likely be affected by the new legislation. By looking at both international standards and previous actions taken by the Chinese government, it is possible to infer the strategic assets that the government is likely to protect against foreign national security threats.

\section{A. International Standards}

In terms of international standards, "[s]trategic assets are generally any tangible or intangible asset or concern of significant value in a given industry, state, or nation. Intelligence gathering and analysis, the ability to use weapons systems more effectively, pharmaceutical, biotech, and genomic firms, bioweapons, [and] environmental knowledge . . . have all been described as strategic assets. ${ }^{, 53}$ In many cases,

these strategic assets are not always characterized as such because of the benefits of their use, but rather because of their symbolic, implied ability to exert influence. Thus, strategic assets provide an advantage both because of the raw force and power of their usage and the implicit persuasive power they hold. $^{54}$

In determining whether an industry is strategic and should be sheltered from foreign ownership, "nation[s] must not only consider the asset's value to [the home nation], but also the strategic value of that asset to the purchasing country. If an asset does in fact hold strategic value, then it necessarily is

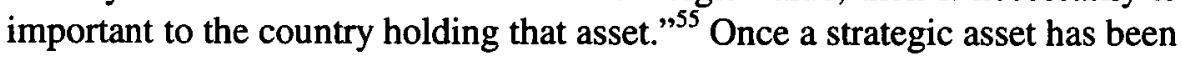
identified and is being threatened by a foreign takeover, then "a country must consider the extent and severity of the sale's national security implications."

The United States, for example, has identified several industries that it considers integral assets worthy of protection due to national security concerns. Airlines and air manufacturers, farmland, telecommunications, and defense are all industries on the list. ${ }^{57}$ Recent legislative actions in the United States provide some factors for determining whether an industry should be identified as a candidate for a national security review of a foreign acquisition. These factors include:

[D]omestic production needed for projected national defense

53. Mamounas, supra note 18 , at 385 .

54. Id. at 386.

55. Id. at 387 .

56. Id. at 387 .

57. Id. at $395-400$. 
requirements whether domestic industries have the capability and capacity to meet national defense requirements, which include such things as human resources, technology, and materials; the potential effects of the transactions on the sales of military goods, equipment, or technology to a country that supports terrorism or proliferates missile technology or chemical or biological weapons and the potential effects of the transaction on U.S. technological leadership in areas affecting U.S. national security. ${ }^{58}$

Although there have been very few instances of the United States exercising its right to reject foreign acquisition based on national security concerns, it is fairly easy to identify the industries that would be subject to future review under these guidelines.

\section{B. Industries Previously Affected in China}

Chinese officials have provided indications as to the types of industries that will be affected by the Article 31 national security review. In August of 2006, the Ministry of Commerce (MOFCOM) issued regulations pertaining to the merger and acquisition of domestic companies by foreign investors. ${ }^{60}$ Those provisions included an antitrust review process similar to that which is codified in Article 31 of the new antitrust law. ${ }^{61}$ The provisions sought to protect the Chinese economy from any threats to its "national economic security," which includes "key industries" and "famous brand names." of those terms were defined in the regulations. ${ }^{63}$ However, the regulations also included a list of strategic sectors in which the State would retain control and therefore are considered subject to national security exceptions to foreign investment. The list includes: military-related manufacturing, power production and grids, petroleum, gas and petrochemicals, telecom manufacturing, coal, civil aviation, and shipping. ${ }^{64}$ In most cases, a SOE exists and dominates the market in these industries, and the government is trying to protect the SOE from foreign competition in the sector. ${ }^{65}$ This situation also

58. Joshua W. Casselman, Note, China's Latest 'Threat' to the United States: The Failed CNOOC-UNOCAL Merger and its Implications for Exon-Florio and CFIUS, 17 IND. INT'L \& COMP. L. REV. 155, 158 (2007) (quoting JAMES K. JACKSON, THE EXON-FLORIO NATIONAL SECURITY TEST FOR FOREIGN INVESTMENT, 3 (2005)(internal quotation marks omitted)).

59. See infra Part $\mathrm{V}$ for a discussion of the foreign investment review process in the United States.

60. Schneider, supra note 28 , at 269.

61. Id.

62. Id. at 280.

63. Id.

64. Landmark Anti-Monopoly Law Passed, ChINA DAILY, Aug. 31, 2007, http://www.chinadaily.com.cn/china/2007-08/31/content_6070127.htm.

65. Bruce M. Owens, Su Sun \& Wentong Zheng, Antitrust in China: The Problem of 
exists for several other industries, including electricity, petroleum, banking, insurance, railroads, and aviation. ${ }^{66}$ In order to determine if an industry is susceptible to national security reviews, investors should first determine if there is a dominant SOE in that sector and whether the government has an incentive to protect the SOE from outside competition.

But not all industries containing a SOE are considered integral to national security, nor will the SOEs in security-related fields be protected forever under the current system. By both regulating an industry and holding an active role in the industry through the SOEs, the Chinese government "plays a double role; it is both the owner of the major players and the referee." realizes that "this dual role is now seen as detrimental to the development of China's market economy," amount of SOE control in many industries. The government has begun to "retreat from the 'non-essential' industries such as machinery, electronics, chemicals, and textiles. Those industries do not tend to . . impinge upon national security." 69 This demonstrates that in non-security related industries containing SOEs, the government is open to new competition from foreign investors. Even in industries that do have national security implications, the government has taken steps to "establish separate regulatory agencies for the key industries and to strip the SOEs in those industries of the regulatory power bestowed upon them in the planned-economy era. In so doing, the Chinese government hopes to separate the government's functions as a player and as a regulator."70 By separating its roles in these security-related sectors, the government is acknowledging that new players are likely to enter the market in the future and need to be treated as equals to the SOEs. Since many of the new players in these industries tend to be foreign firms attempting to enter the economy, these actions demonstrate the government's willingness to accept foreign competition even in security-related sectors.

The international concern surrounding China's lack of a clear definition for "national security" under Article 31 of the new antitrust law is largely based on China's past, and does not take into account the current economic landscape of the country. Comparing the law to previous regulations indicates that the industries that will be affected are fairly identifiable and consistent with international norms. Assuming that Chinese regulatory officials apply the new law according to international standards (and their own previous standards), it is likely that foreign investors will be able to identify whether their proposed merger or acquisition will be subject to the heightened level of review. Furthermore, even if the law is used to shift China towards economic protectionism due to national security in certain industries, most free trade

Incentive Compatibility, 1 J. COMPETITION L. \& ECON. 123, 129 (2005).

66. Id.

67. Id.

68. Id.

69. Id.

70. Id. at 129-30. 
agreements allow this sort of activity on a limited basis.

\section{INTERNATIONAL FREE TRADE AGREEMENTS AND NATIONAL SECURITY EXCEPTIONS}

Among the prominent international free trade agreements, there are several exceptions that allow member nations to legally deny foreign investment in sectors they deem integral to national security. For example, the WTO, of which China became a member in 2001, allows for national security exceptions to free trade in several sectors. ${ }^{71}$ Similarly, the ASEAN, which China is closely associated with, though not a member of, gives member nations the right to deny the free flow of goods and services if it negatively affects national security. ${ }^{72}$ Even the European Union (EU) and the North American Free Trade Agreement (NAFTA) give member states the ability to deny foreign investment based on national security concerns. ${ }^{73}$ In light of these common exceptions to international free trade agreements, China has the right to follow international norms and review foreign investment based on national security.

\section{A. The World Trade Organization}

The WTO agreements contain several provisions allowing member states to deny foreign investment due to national security interests. Under Article XIV (General Exceptions) of the General Agreement to Trade in Services of the WTO, a member state may prevent foreign investment if it threatens the health, safety, or national security of its citizens. ${ }^{74}$ The exception reads:

Subject to the requirement that such measures are not applied in a manner which would constitute a means of arbitrary or unjustifiable discrimination between countries where like conditions prevail, or a disguised restriction on trade in services, nothing in this Agreement shall be construed to prevent the adoption or enforcement by any Member of measures:

71. See infra Part III.A.

72. US-ASEAN Bus. Council, The ASEAN Free Trade Area and Other Areas of ASEAN Cooperation, http://www.us-asean.org/afta.asp (last visited Nov. 30, 2008) [hereinafter ASEAN].

73. See infra Part III.C.

74. General Agreement on Trade in Services, Apr. 15, 1994, Marrakesh Agreement Establishing the World Trade Organization, Annex 1B, art. XIV, The Legal Texts: The Results of the Uruguay Round of Multilateral Trade Negotiations 284 (1999), 108 Stat. 4809, 1869 U.N.T.S. 183 (1994), available at http://www.wto.org/english/docs_e/legal_e/26-gats.pdf. 
(a) necessary to protect public morals or to maintain public order;

(b) necessary to protect human, animal or plant life or health;

(c) necessary to secure compliance with laws or regulations which are not inconsistent with the provisions of this Agreement including those relating to:... (iii) safety. ${ }^{75}$

Furthermore, Article XIV gives specific exceptions for national security situations:

Article XIV bis - Security Exceptions: 1. Nothing in this Agreement shall be construed:

(a) to require any Member to furnish any information, the disclosure of which it considers contrary to its essential security interests; or

(b) to prevent any Member from taking any action which it considers necessary for the protection of its essential security interests:

(i) relating to the supply of services as carried out directly or indirectly for the purpose of provisioning a military establishment; (ii) relating to fissionable and fusionable materials or the materials from which they are derived;

(iii) taken in time of war or other emergency in international relations; or

(c) to prevent any Member from taking any action in pursuance of its obligations under the United Nations Charter for the maintenance of international peace and security. ${ }^{76}$

Several other WTO provisions also contain exceptions allowing member states to take action that may be contrary to free trade in order to maintain national security. For example, Article XXIII, section 2 of the Agreement on Government Procurement provides that:

Subject to the requirement that such measures are not applied in a manner which would constitute a means of arbitrary or 
unjustifiable discrimination between countries where the same conditions prevail or a disguised restriction on international trade, nothing in this Agreement shall be construed to prevent any Party from imposing or enforcing measures: necessary to protect public morals, order or safety ... ${ }^{77}$

The inclusion of these exceptions in several different areas of the WTO agreements demonstrates that the international community is committed to preserving national security at the expense of free trade. In order for free trade to prosper, the security of each nation must first be guaranteed. Article 31 of the Chinese antitrust law is, as currently written, in harmony with these WTO provisions. Article 31 gives the Chinese government the right to review foreign investment for national security threats in the same way that the WTO provisions allow member nations to deny international trade if it negatively harms national security.

\section{B. The Association of Southeast Asian Nations}

Similarly, ASEAN member nations have the ability to reject foreign investment due to national security concerns. Under the Association's "General Exceptions" clause, any member may reject the free flow of goods which "a country deems necessary for the protection of national security, public morals, the protection of human, animal or plant life and health, and protection of articles of artistic, historic, or archaeological value." Although China is not currently a member of the ASEAN free trade agreement, it is a member of the "ASEAN Plus Three" economic group, which includes the ASEAN nations plus China, Japan, and South Korea. ${ }^{79}$ The group was created to extend economic cooperation between the ASEAN nations and the other large economies of Asia. ${ }^{80}$ If China were to become a full member of the ASEAN economic free trade zone, Article 31 of the new antitrust law would also be in harmony with the national security exceptions found in the ASEAN guidelines.

\section{The European Union and North American Free Trade Agreement}

Many of the prominent international free trade agreements which China is not party to also allow national security exceptions to foreign investment. The EU, for example, allows its Member States to apply merger and acquisition

77. Final Act Embodying the Results of the Uruguay Round of Multilateral Trade Negotiations, Apr. 15, 1994, Agreement on Government Procurement, Annex 4(b), art. XXIII section 2 (1994), available at http://www.wto.org/english/docs_e/legal_e/gpr-94_e.pdf.

78 ASEAN, supra note 72.

79. AsSOCIATION OF SOUTH EAST Asian Nations, ASEAN Plus Three CoOperation, II 1, http://www.aseansec.org/16580.htm (last visited Nov. 30, 2008).

80. Id. II 2. 
regulations in order to protect national or public security interests. ${ }^{81}$ Under these antitrust regulations, members of the EU may "take appropriate measures to protect legitimate interests other than those taken into consideration by this Regulation and compatible with the general principles and other provisions of Community law." 82. The regulation further explains that "[p]ublic security, plurality of the media and prudential rules shall be regarded as legitimate interests ...."83 Member States also have the ability to apply these national security exceptions to other areas of interest or industries if they first report the application to the European Commission for approval. ${ }^{84}$ The regulations state that "[a]ny other public interest must be communicated to the Commission by the Member State concerned and shall be recognized by the Commission after an assessment of its compatibility with the general principles and other provisions of Community law before the measures ... may be taken." ${ }^{, 55}$ Once again, the national security interests of each Member State are preserved through the regulation of foreign mergers and acquisitions.

Similar to the ASEAN, EU, and WTO exceptions, NAFTA allows its member nations to deny foreign investments based on national security interests through Article 2102 (National Security Exceptions) of the Agreement. Article 2102 states:

[N]othing in this Agreement shall be construed: (a) to require any Party to furnish or allow access to any information the disclosure of which it determines to be contrary to its essential security interests; [or] (b) to prevent any Party from taking any actions that it considers necessary for the protection of its essential security interests. ${ }^{86}$

Article 2102 is referenced throughout the NAFTA provisions as a reasonable exception to many free trade provisions. ${ }^{87}$ The inclusion of Article 2102 in the NAFTA provisions further demonstrates that many free trade agreements consider national security exceptions to be an integral part in the overall construction of the agreement.

Free trade agreements are an essential tool of an integrated global economy. ${ }^{88}$ They help to open borders and make trade possible between many

81. Council Regulation 139/2004, On the Control of Concentrations Between Undertakings (the EC Merger Regulation), art. 21(4), 2004 O.J. (L 24) 17 [hereinafter EU Merger Regulation].

82. Id.

83. Id.

84. Id.

85. Id.

86. North American Free Trade Agreement, U.S.-Can.-Mex., art. 2102, Dec. 17, 1992, 32 I.L.M. 289, 605 [hereinafter NAFTA].

87. See generally id.

88. See generally Export.gov, U.S. Free Trade Agreements, http://www.export.gov/fta/ (last visited Nov. 30, 2008). 
nations. ${ }^{89}$ However, before any nation is willing to enter into a free trade agreement with other nations, it must first be assured that its national security will not be threatened by the influx of foreign goods, services, and investment. Therefore, it is proper that free trade agreements include some type of provision allowing member nations the right to take action when necessary to protect security interests. The WTO, ASEAN, EU and NAFTA agreements have all taken note of this and have provided national security exceptions to the free trade blocs they establish. Article 31 of China's antitrust law also takes note of this national security requirement and gives the Chinese government the ability to exercise its right to protect national security under its own free trade obligations. Article 31 might initially be startling due to protectionist implications and China's history with isolationism, but on its face, it is in harmony with the prominent international trade agreements concerning this issue. Furthermore, China is not the only nation taking advantage of the national security exception found in many of these free trade agreements.

\section{INTERNATIONAL EXAMPLES OF ECONOMIC PROTECTIONISM AND NATIONAL SECURITY}

Similar to Article 31 of the Chinese antitrust law, many nations reserve the right to deny foreign mergers or acquisitions of important domestic assets based on national security concerns. ${ }^{90}$ The industries considered integral to national security, however, vary widely depending on each individual nation's interests. ${ }^{91}$ The industries usually affected by this exception tend to be the typical energy and defense sectors, ${ }^{92}$ but other non-traditional economic "crown jewels" may also be protected for national security concerns. ${ }^{93}$ Regardless of the industry chosen to be insulated from foreign competition, it is common practice in the global economy for nations to protect certain domestic assets from foreign investors.

\section{A. Governmental Oversight and Procedure}

Several nations have set up specific procedures and permanent governmental entities to review bids by foreign companies seeking to gain an interest in domestic assets. ${ }^{94}$ These entities can be seen in many of the major European economic powers.

89. Id.

90. E.g. Sud, supra note 14 , at 1313 (noting that many countries restrict commercial ventures, and discussing Japan's national security restrictions in particular).

91. Hon. Pamela Jones Harbour, Developments in Competition Law in the European Union and the United States: Harmony and Conflict, 19-SPG INT'L L. PraCTICUM 3, 5 (2006).

92. See id.

93. Cf. Editorial, Takeover Bids by State-Owned Firms, GlobE AND Mal,, Oct. 12, 2007, at A26. [hereinafter Takeover Bids].

94. Sud, supra note 14, at 1312-13. 
The Panel on Takeovers and Mergers ("The Panel") reviews foreign takeover bids in the United Kingdom for possible national security risks. ${ }^{95}$ The Panel reviews each case based on the statutes set out in the City Code on Takeovers and Mergers. ${ }^{96}$

Similarly, "Germany and Austria . . . have developed a . . system of takeover regulation, whereby entities exist both in and out of the government to ensure that [foreign] companies are complying with statutory laws, and more significantly, that those companies meet investment approval standards." Case in point:

[1]n Germany several years ago, the Bundeskartellamt decided to prohibit the proposed merger of E.on and Ruhrgas. The parties, however, persuaded the German Economics Ministry to use the authority reserved to it in Germany's competition law to override the decision of the Bundeskartellamt and allow the merger to be consummated. ${ }^{98}$

France also requires a review by the Treasury Department of the French Ministry of Economics and Finance if a merger or acquisition results in foreign ownership of twenty-percent or more of a domestic company. ${ }^{99}$

This trend is not limited to European nations. When Japan first developed a review system for foreign investment under their antitrust laws, many international observers believed it was an attempt to isolate Japan from the world economy. ${ }^{100}$ However, the Japanese government demonstrated in practice that the measures were not meant to isolate Japan; rather, the regulations were there to protect its legitimate security interests. Japan now requires all foreign investments in domestic assets to be referred to the Committee on Foreign Exchange and Other Transactions for recommendations on various matters, including whether the transaction affects national security. ${ }^{101}$ Similarly, the Reserve Bank of India is charged with the regulation of foreign investment in domestic assets. ${ }^{102}$ Foreign transactions will only be permitted in India if the Bank first deems those actions to be within the overall national interest. ${ }^{103}$

Canada has also moved towards requiring more stringent governmental

95. Id. at 1312 .

96. Id.

97. Id.

98. Jones Harbour, supra note 91.

99. Sud, supra note 14 , at 1312-13.

100. See generally Alex Y. Seita \& Jiro Tamura, The Historical Background of Japan's Antimonopoly Law, 1994 U. ILL. L. REV. 115 (1994).

101. Sud, supra note 14, at 1313.

102. Id. at 1314.

103. Id. 
oversight in foreign investment. ${ }^{104}$ For many years, Canada was one of the few nations that did not screen foreign investment based on national security concerns. ${ }^{105}$ However, Canadian citizens became increasingly concerned with the buying power of large state-owned enterprises and investment pools from countries with questionable relationships with Canada. ${ }^{106}$ Specifically at issue was the substantial buying power of sovereign funds from the Middle East and other oil exporting nations. This caused Prime Minister Stephen Harper to assert that national security should be a consideration for reviewing foreign investment, but cautioned against its use as a tool of economic protectionism. ${ }^{107}$ Canada already has a system in place for reviewing foreign investments in domestic companies under the Investment Canada Act (ICA) of 1985, but the Act does not include a national security component to its review process. ${ }^{108}$ This almost changed in 2005, when the state-owned China Minmetals Corporation attempted to acquire the domestic Canadian mineral company Noranda, Inc. ${ }^{109}$ The takeover bid was later dropped, but the bid led to a proposed amendment to the ICA by liberal members of government in order to ensure its ability to review and block foreign transactions based on national security concerns. ${ }^{110}$ The liberal government members were defeated before they were able to pass the amendment, but as Prime Minister Harper indicated, it appears that national security will now be considered by the conservative government as a viable reason for reviewing foreign investment in the country. ${ }^{11}$

In summary, the Chinese government is not alone in its attempt to set up a regulatory system that will subject foreign investors to a heightened level of review in industries related to national security. Article 31 of the antitrust law seems to embody a universal concern that most governments have for protecting the national security interests of their nation as they face an increasingly global economy. This sense of concern may be well-founded when it is applied to the typical industries, such as energy or national defense, but is decidedly questionable when applied to other, non-traditional industries.

\section{B. Examples of Protected Industries from around the Globe}

Throughout the world, nations have chosen to insulate a myriad of industries and companies from foreign ownership using national security as the

104. See Takeover Bids, supra note 93.

105. Id.

106. Id.

107. Id.

108. Investment Canada Act, R.S.C., ch. I-21.8, part IV (1985) (1st Supp.), available at http://strategies.ic.gc.ca/epic/site/ica-lic.nsf/en/h_lk0007le.html.

109. Marcela B. Stras et al., International Legal Developments in Review: 2006, 41 INT'L LAw. 749, 756 (2007).

110. Id.

111. Id. 
justification for doing so. ${ }^{112}$ Among the protected industries, some general themes develop as to the types of companies that are typically affected. ${ }^{113}$ However, specific industries considered worthy of protection differ depending on the nation and its national security needs.

For example, Australia maintains strict protectionist policies on its telecommunications sector. ${ }^{114}$ Many international observers believe that "[a]mong telecommunications sectors in English-speaking nations, Australia's restrictions are the most stringent." "The country places restrictions on the ability of foreigners to own dominant telecommunication carriers. ${ }^{116}$ Under these regulations, the majority of the board of directors in any telecommunications company, including the chairman, must be Australian citizens. ${ }^{117}$ Furthermore, the Australian government has placed restrictions on foreign ownership in urban land, banking, aviation, airports, and shipping. ${ }^{118}$ Although these regulations are somewhat stricter than most common-wealth nations, they still concern industries that are typically affected by national security exceptions to free trade.

Foreign investment restrictions are not limited to typical national security industries. Several nations also limit foreign ownership in less traditional economic sectors and businesses. The nations view these sectors as integral to the livelihood of the nation as a whole, and therefore worthy of national security protection. France, for example, has identified the domestic food and beverage company Danone to be a "national treasure" worthy of protection, and therefore has denied mergers or acquisitions of the company from international investors such as Pepsico. ${ }^{119}$ Similarly, Iceland has "a complete ban of foreign ownership in its fishing [industry]" due to the country's reliance on that industry as a significant source of employment and income. ${ }^{120}$ Although these industries would hardly be considered "integral to national security" by most international standards, they are important enough to warrant protectionist policies by their home nations.

Although Article 31 of the new Chinese antitrust law has the potential of being applied to a wide variety of industries, the inclusion of non-security related industries in the list of exceptions still seems to be somewhat within international norms. As shown through previous examples, many western and economically "open" nations have chosen to protect domestic industries in ways that are not always in harmony with international standards of free trade. Of course, these practices need to be kept in check if the major free trade

112. Mamounas, supra note 18 , at 402 .

113. See supra Part II.

114. Mamounas, supra note 18 , at 402 .

115. Id.

116. Id.

117. Id.

118. Id.

119. Harbour, supra note 91 , at 5 .

120. Mamounas, supra note 18 , at 402 . 
agreements are going to succeed; however, some leeway should be granted to the Chinese government if it initially chooses to apply Article 31 to nontraditional sectors. As demonstrated below, even the United States, considered to be the most open and free market in the world, has followed recent international examples and has moved towards a policy of economic protectionism based on national security concerns.

\section{NATIONAL SECURTY AND THE MOVE TOWARDS ECONOMIC PROTECTIONISM IN THE UNITED STATES}

\section{A. The History of Foreign Investment Review in the United States}

Traditionally, the U.S. government has had a very limited ability to review foreign investment in domestic assets due to national security reasons. ${ }^{121}$ In order for the President to deny foreigners their equal property rights in domestic assets, a national state of emergency had to be declared. ${ }^{122}$ This was the case until 1975, when President Gerald Ford created the Committee on Foreign Investments in the United States (CFIUS) and gave it the responsibility of "monitoring the impact of foreign investment in the United States, both direct and portfolio, and for coordinating the implementation of United States policy in such investment." ${ }^{\prime 23}$ The committee's principal duty was to gather information for the executive branch about the possible effects of foreign investment in certain domestic enterprises on national security. ${ }^{124}$ The creation of this committee was a direct reaction to the increased international investment capabilities of members of the Organization of Petroleum Exporting Countries (OPEC). ${ }^{125}$ The increased spending abilities of these nations were seen as a security threat to domestic U.S. companies, specifically in the oil and defense sectors. ${ }^{126}$ However, neither CFIUS nor the President had the statutory ability to reject foreign investment if it threatened the national security of the United States. ${ }^{127}$

This lack of ability to take any meaningful action led to the Exon-Florio Amendments of the Omnibus Trade and Competitiveness Act in 1988, which gave the President the power to both investigate and block foreign investments that might threaten national security. ${ }^{128}$ The Exon-Florio Amendment was a

121. Casselman, supra note 58, at 157.

122. Id.

123. Sud, supra note 14, at 1315 (quoting Foreign Investment on U.S.: Hearing Before the S. Comm. On Banking, Housing, and Urban Affairs (2005) (statement of Patrick A. Mulloy, Member, U.S.-China Economic Security Review Commission)).

124. Sud, supra note 14 , at 1315.

125. Id.

126. Id.

127. Id.

128. Mamounas, supra note 18 , at 388 . 
direct reaction to the government's fear that Japanese acquisition of domestic assets would negatively affect the security of the nation. ${ }^{129}$ The President delegated his investigative responsibilities under Exon-Florio to CFIUS. ${ }^{130}$

The original Exon-Florio Amendments contained a four-step process for analyzing and denying foreign investment in U.S. companies:

(1) voluntary notice by the companies [of the investment activity], (2) a 30-day review to identify whether there are any national security concerns, (3) a 45-day investigation to determine whether those concerns require a recommendation to the President for possible action, and (4) a Presidential decision to permit, suspend, or prohibit the acquisition. ${ }^{131}$

Foreign companies had the ability to forego the review if they deemed their activity to be outside the scope of a national security review, but to do so would subject the company to indefinite Presidential review if it was later determined that the transaction had negative implications. ${ }^{132}$ There were many factors the committee considered when conducting a national security review, including:

(1) domestic production needed for projected national defense requirements, (2) the capability and capacity of domestic industries to meet national defense requirements, including the availability of human resources, products, technology, materials, and other supplies or services, (3) the control of domestic industries and commercial activity by foreign citizens as it affects the capability and capacity of the United States to meet the requirements of national security, ... (5)the potential effects of the proposed or pending transaction on United States international technological leadership in areas affecting United States national security. ${ }^{133}$

If CFIUS determined that there was "[1] credible evidence ... to believe that a foreign controlling interest might take action that threatens to impair national security and (2) laws other than Exon-Florio . . . are inadequate or inappropriate to protect national security," then the President had the authority to prohibit the transaction. ${ }^{134}$ The President had to provide a written report

129. Casselman, supra note 58, at 157.

130. Sud, supra note 14 , at 1316.

131. Id.

132. Id.

133. Mamounas, supra note 18 , at 389-90.

134. Sud, supra note 14, at 1316. (quoting U.S. Gov'T ACCOUNTABILITY OFFICE, ENHANCEMENTS TO THE IMPLEMENTATION OF EXON-FLORIO COULD STRENGTHEN THE LAW'S EFFECTIVENESS 1, 9-10 (Sept. 2005) [hereinafter GAO REPORT] ). 
listing the reasons for the denial of the merger or acquisition, but the decision was not judicially reviewable. ${ }^{135}$ However, the President could block an action if: "(1) the Committee has informed the companies in writing that their acquisition was not subject to Exon-Florio or had previously decided to forego investigation, or (2) the President has previously decided not to act on that specific acquisition under Exon-Florio."136

More importantly, the Exon-Florio Amendments did not explicitly define the term "national security" anywhere in the legislation. ${ }^{137}$ The only guidelines the legislation gave concerning the type of industries that should be reviewed were "companies providing technology to the military or to the defense industrial base." 138 The Amendment also gave some indication as to the economic activity that would not need to be reviewed for national security concerns, including "acquisitions of businesses in industries having 'no special relation to national security.""139 The regulations cite various examples of items that would not give rise to national security concerns, such as toys, games, hotels, food products, and legal services. ${ }^{140}$ The term "national security" was intentionally left undefined so that it could be "interpreted broadly without limitation to a particular industry." ${ }^{141}$ The Department of Treasury, which has responsibility for application of Exon-Florio, has rejected any proposals that give a clearer or more definitive definition to "national security" in the legislation. ${ }^{142}$ This is not unlike the strategy taken by the Chinese government in its decision to leave "national security" undefined in Article 31 of the new antitrust law.

In 1993, the United States amended Exon-Florio through the 1993 Defense Authorization Act, an amendment known as the Byrd Amendment. ${ }^{143}$ The Byrd Amendment made three significant changes to Exon-Florio. The amendment first requires:

a separate review process focused on national origin, which used a lower threshold requirement and more ambiguous wording in order to permit greater inclusiveness in conducting reviews. Secondly ... by requiring evaluation of the potential effects of a transaction, "expanded the scope of national security factors for consideration, laying the foundation for the consideration of third-party transactions.' Finally, the Byrd

135. Mamounas, supra note 18 , at $389-90$.

136. Sud, supra note 14, at 1317 (quoting GAO Report, supra note 134, at 10).

137. Id.

138. Id. at 1318 (quoting Eric Simonson, Specialized Areas of Concem in Acquisition Transactions, in A GUIDE TO MERGERS \& ACQUISITIONS 243, 262 (2006).

139. Id. (quoting Simonson, supra note 138).

140. Id.

141. Casselman, supra note 58, at 157 (quoting JACKSON, supra note 58, at 2).

142. Mamounas, supra note 18 , at 391 .

143. Id. at 390. 
Amendment requires an immediate report to Congress whether or not action is taken following an investigation, as well as a Quadrennial Report detailing any credible evidence of either industrial espionage or a coordinated attempt by either foreign countries or companies to usurp American control over leading sectors of technology. ${ }^{144}$

The amendment changed some of the transparency issues with ExonFlorio and broadened its potential application, but did not significantly alter the definition of "national security" or the industries to which it can be applied. ${ }^{145}$

Since the creation of CFIUS and the Exon-Florio Amendment, only one foreign investment has been officially blocked by the President. Twenty-five cases have passed into full investigation, and of those cases only twelve were sent to the President for a decision. ${ }^{146}$ Of the twelve cases sent to the President, only one has been rejected due to national security implications. In 1990, President George H. W. Bush ordered the China National Aero-Technology Import and Export Corporation to sell its interest in Mamco Manufacturing. ${ }^{147}$ However, "the practical effect of Exon-Florio is that foreign entities have voluntarily withdrawn bids to avoid a full CFIUS investigation much more frequently than they have been prohibited from acquiring U.S. companies .... [The national security review process can] persuade foreign entities to restructure the terms of the acquisition in ways that address CFIUS's security concerns." 148 Therefore, although the power given to the President and CFIUS has been exercised infrequently, the mere threat of a review has led a large number of foreign investors to either withdraw their bids or restructure their offers.

\section{B. Recent Legislative Developments in the United States concerning} Foreign Investment and National Security

The United States government, through CFIUS, has not officially blocked a foreign merger or acquisition since the early $1990 \mathrm{~s} ;{ }^{149}$ however, political pressure from Congress and the American public has effectively denied two recent foreign acquisitions due to national security concerns. ${ }^{150}$ It has also led to the passage of the Foreign Investment and National Securities Act of 2007 (FINSA), which strengthens the federal government's ability to deny foreign

144. Id. (quoting Christopher R. Fenton, Note, U.S. Policy Towards Foreign Direct Investment Post-September 11: Exon-Florio in the Age of Transnational Security, 41 ColuM. J. TRANSNAT'LL. 195, 208 (2002)).

145. Id.

146. Casselman, supra note 58 , at 159-60.

147. Mamounas, supra note 18 , at 393.

148. Casselman, supra note 58 , at $160-61$.

149. See supra Part I.

150. Casselman, supra note 58, at 160-61. 
investment in the United States. ${ }^{151}$ These measures have increasingly pushed the United States towards economic isolationism in industries related to national security.

\section{i. CNOOC-Unocal Bid}

In June of 2005, the Chinese National Offshore Oil Corporation (CNOOC) placed an unsolicited bid of $\$ 18.5$ billion to buy the American oil company Unocal. ${ }^{152}$ CNOOC was a State-Owned Enterprise of the People's Republic of China, and the bid to buy Unocal was being funded in large part by the State Central Bank and the Chinese government itself. ${ }^{153}$ After the bid was announced, forty-one members of the United States Congress urged CFIUS to review the takeover bid for national security implications in the energy sector. ${ }^{154}$ The Congressional members were "very concerned about China's ongoing and proposed acquisition of energy assets around the world, including those in US [sic]." ${ }^{155}$ Congress then passed House Resolution $344,{ }^{156}$ which came to two significant conclusions concerning the takeover bid:

(1) the Chinese state-owned China National Offshore Oil Corporation, through control of Unocal Corporation obtained by the proposed acquisition, merger or takeover of Unocal Corporation, could take action that would threaten to impair the national security of the United States; and (2) if Unocal Corporation enters into an agreement of acquisition, merger, or takeover of Unocal Corporation by [CNOOC], the President should initiate immediately a thorough review of the proposed acquisition, merger, or takeover. ${ }^{157}$

The Chinese government was extremely critical of the measure, saying it was an unnatural interference with legitimate international trade. ${ }^{158}$

The President chose not to take any significant action on the proposed merger, likely concerned that it would strain Sino-American relations. ${ }^{159}$ However, the Congressional uproar caused by the CNOOC bid had the effect of dissuading the Chinese from entering into such a politically charged

151. Jonathan C. Stagg, Note, Scrutinizing Foreign Investment: How Much Congressional Involvement is too Much?, 93 IOWA L. REV. 325, 347 (2007).

152. Mamounas, supra note 18 , at 403.

153. Id.

154. Id. at 404 .

155. Id. (quoting John Chan, China's Bid for Unocal Heightens Tension with the US, World Socialist Website (July 6, 2005), http://www.wsws.org/articles/2005/jul2005/chinj06.shtml).

156. H. R. Res. 344, 109th Cong. (2005).

157. Mamounas, supra note 18 , at 405 (referencing H. R. Res. 344, supra note 157).

158. Mamounas, supra note 18 , at 406.

159. Id. at 408 . 
acquisition. On August 2, 2005, CNOOC withdrew its bid for Unocal and sought oil-related acquisitions elsewhere. ${ }^{160}$ Although the foreign acquisition was not officially denied by CFIUS, the political climate surrounding the bid was enough to initiate an economic protectionist outcome based on national security concerns.

\section{ii. Dubai Ports World Acquisition}

Similar to the CNOOC bid, national security concerns caused another foreign investment in domestic assets to be effectively denied when the proposed acquisition of Peninsular \& Oriental Steam Navigation Company by Dubai Ports World, a company owned by the Dubai government, led to Congressional uproar. ${ }^{161}$ In 2005, Dubai Ports World entered into an agreement to buy $\mathrm{P} \& \mathrm{O}$, a London-based company, which ran port operations in six United States ports. ${ }^{162}$ After a preliminary investigation, CFIUS found that the deal did not threaten national security interests, and unanimously agreed to allow the transaction to proceed. ${ }^{163}$ Congress then became concerned that a thorough review had not been conducted and prompted Dubai Ports World to resubmit the acquisition for review. ${ }^{164}$ Critics of the deal were concerned that although the UAE's government is pro-United States in its policies, many of the $9 / 11$ hijackers used the UAE as an operational and financial base before the attack. ${ }^{165}$ Supporters of the proposed acquisition, including the Bush administration, pointed to the fact that Dubai Ports World would not be in charge of any port security duties as a result of the acquisition. ${ }^{166}$ While the second CFIUS review was still in progress, Dubai Ports World responded to the strong negative reactions by restructuring its bid for $\mathrm{P} \& O$ and agreeing to sell the operations of all U.S. ports to a U.S. company. ${ }^{167}$ Once again, protectionist assertions in the United States effectively blocked a foreign acquisition due to national security concerns.

\section{iii. Recent Legislative Developments}

The CNOOC and Dubai Ports World events led to several legislative reactions that have changed the landscape of foreign investment in the United States. Most significantly, it led to the passage of FINSA. "FINSA is a broad, sweeping revision of Exon-Florio that leaves very little of the former language

160. Casselman, supra note 58, at 164.

161. Deborah M. Mostaghel, Dubai Ports World Under Exon-Florio: A Threat to National Security or a Tempest in a Seaport?, 70 ALB. L. REV. 583, 606-07 (2007).

162. Id. at 606.

163. Id.

164. Id.

165. Id.

166. Id. at 607 .

167. Id. 
intact." 168 It changes the process and time frame by which reviews are conducted by CFIUS. ${ }^{169}$ It also clarifies which transactions the statute is applicable to, and includes additional factors that may be considered in an investigation. ${ }^{170}$ These factors include "whether the transaction has a securityrelated impact on critical infrastructure and critical technologies and whether it is a foreign-government-controlled transaction."171 CFIUS may also consider any additional factors it deems appropriate, which is a much broader power of review than CFIUS previously held under Exon-Florio. ${ }^{172}$

FINSA also changed CFIUS by adding more members to the committee, including the Director of National Intelligence, and allowing CFIUS to conduct investigations without prior voluntary submission (Exon-Florio required companies to submit for review to CFIUS voluntarily). ${ }^{173}$ "If a foreign government controls the acquirer, as with the Dubai and UNOCAL transactions, the acquisition will attract a review, as will deals involving critical US [sic] infrastructure such as the proposed ports acquisitions, significant energy assets, or critical technology." 174 Finally, FINSA also allows CFIUS to place conditions on the proposed acquisition that need to be met before the transaction will be allowed to proceed. ${ }^{175}$ This allows CFIUS to restructure acquisition agreements to the benefit of all parties involved, without denying the deal as a whole due to a small national security risk. ${ }^{176}$

Many critics believe FINSA reaches too far with its additional provisions and borderlines on economic isolationism. ${ }^{177}$ "FINSA's most significant effect is to politicize the area of foreign investment due to its dramatically increased congressional-reporting requirements."178 Several members of Congress, including the House Speaker, Majority and Minority leaders, Chairpersons of the Banking, Housing, Urban Affairs, and Financial Services Committees, and other Congressional leaders will all have access to confidential corporate documents during the review. ${ }^{179}$ This level of accessibility to sensitive materials will inevitably lead to information leaks, special-interest jockeying, and other highly political effects that previously did not influence most foreign

168. Stagg, supra note 151 , at 345 .

169. Id.

170. Id.

171. Id. at 347.

172. Id. at 347-48.

173. Robert A. McTamaney, Dealmakers Face Regulatory Hurdles for Cross-Border Deals: Exon-Florio Amended to Increase Scrutiny of Foreign Investment in the US, INVESTMENT DEALERS' DigeST, Sept. 24, 2007, available at http://www.clm.com/ docs/idd09242007.pdf.

174. Id.

175. Stagg, supra note 151 , at 349 .

176. Id.

177. Id. at 352 .

178. Id.

179. Id. 
investment in the United States. ${ }^{180}$ It could also lead to political upheaval and denial of non-security related foreign investments based purely on patriotic hubris. For example, "[w]hen the Japanese bought Rockefeller Plaza in 1989, there was an outcry based on the perceived inappropriateness of a foreign owner taking over a beloved American landmark. But aside from hurt pride at loss of ownership, Americans had no real reason to dispute the soundness of that business decision."

\section{RECOMMENDATIONS}

The analysis of foreign investment and national security under China's new antitrust law leads to several recommendations for parties on all sides of the issue. These recommendations include suggestions for the Chinese government as it begins to implement the national security provision, ideas for companies looking to invest in China that may be worried about the new law, and warnings to CFIUS and the United States government as it implements its own national security provisions for foreign investment.

\section{A. China}

It is extremely important for the NPC to quickly develop and expand the administrative regulations associated with Article 31 of the new antitrust law. Administrative duties need to be delegated to the State organization that will supervise the implementation of this law. That organization must draft specific guidelines that will give foreign investors an idea as to types of industries that will be affected by the law. At the very least, the term "national security" needs to be defined so foreign investors can assess whether their proposed merger or acquisition will be subject to the new law. The government must avoid the temptation to define the law too broadly to include industries outside traditional security-related sectors. Defining the law broadly will allow the government some flexibility in its application, but will also create more uncertainty among foreign investors. The definition must be sufficiently clear and describe the industries that will most certainly be affected, as well as the industries that will not be affected. This will help assuage the fears of foreign investors that their transaction might be arbitrarily blocked by corrupt government officials. Regardless of the protectionist policies of other nations, including the United States, the Chinese economy will best be served by establishing a clear definition of "national security" under Article 31.

Second, China needs to keep its market open to foreign investors in order to sustain the growth of its economy. ${ }^{182}$ The Chinese market is still relatively young and does not have the amount of domestic capital needed for continued 
long-term growth. ${ }^{183}$ The capital infusion it receives from foreign investors is what is driving most of the growth that would otherwise be outside the reach of domestic investors. ${ }^{184}$ Foreign investment also brings new technology and management experience to the immature market. ${ }^{185}$ Without the technology and managerial know-how, many Chinese industries would fall behind their global competitors in terms of productivity and quality of the products they offer. ${ }^{186}$ This is especially apparent in highly technical sectors, such as banking and financials. ${ }^{187}$ Therefore, in order to preserve the astounding growth the Chinese economy has achieved in recent years, the government needs to understand the main factors that are driving most of that growth: foreign investors.

Furthermore, the NPC needs to limit the amount of corruption within the ranks of the state organization overseeing the application of Article 31. It is well known that corruption is a major roadblock to progress within the Chinese government. ${ }^{188}$ Many state officials have proven in the past to be susceptible to favoritism and bribery. ${ }^{189}$ If this corruption is not controlled, it will have a significant impact on the ability of foreign investors to enter the Chinese economy. Corrupt officials could be persuaded to use the law to arbitrarily block foreign competition in the domestic economy at the behest of domestic enterprises. This would be detrimental to both foreign investors and the Chinese economy. China has greatly benefited from an influx of foreign investment in recent years, ${ }^{190}$ and any artificial obstructions to this investment would only serve to hamper the continued growth of the economy. ${ }^{191}$ It is in the best interest of the PRC to keep corruption at a minimum in any circumstance, but a complex global market requires special attention to this matter.

\section{B. Foreign Investors}

Foreign investors looking to expand into China should consider whether their business has a substantial influence on industries that are typically affected by national security laws. As described previously, ${ }^{192}$ these industries tend to

183. Id.

184. Id.

185. Id. at 283.

186. Id.

187. $I d$.

188. Edward Cody, China Cracks Down on Corruption, WASH. Post, Feb. 15, 2006, at A18, available at http://www.washingtonpost.com/wp-dyn/content/article/2006/02/14/ AR2006021400672.html.

189. Id.

190. Anil Kumar, Does Foreign Direct Investment Help Emerging Economies?, 2 ECONOMIC LETTER 1, Jan. 2007, available at http://www.dallasfed.org/research/eclett/2007/ el0701.html.

191. Id.

192. See supra Part II. 
be related to national defense, energy, hazardous chemicals, and telecommunications. As long as the NPC chooses to apply its competition law in accordance with international standards, and keeps corruption to a minimum, these sectors should be fairly identifiable. It is important to monitor the developments in state regulatory agencies to see how the law is being applied. Furthermore, since a large part of the Chinese antitrust law has been adopted from other major anti-monopoly doctrines around the world, ${ }^{193}$ foreign investors should first consider whether their merger or acquisition would raise national security questions under those systems of anti-monopoly law. ${ }^{194}$ If the takeover were to raise a red flag in the United States or the European Union for antitrust violations, then it is also likely that the Chinese government will subject the transaction to a national security review.

\section{United States}

Finally, the United States government needs to tread carefully as it applies its new powers under FINSA. In an increasingly globalized economy, there are going to be many situations where foreign companies will be looking to acquire domestic U.S. companies that may never have been under foreign ownership. This is especially apparent given the weakening of the dollar compared to many foreign currencies. ${ }^{195}$ A weak dollar puts many U.S. companies "on sale" in the eyes of foreign competitors. ${ }^{196}$ This is a reality of the emerging global economy. Therefore, it is imperative that CFIUS and Congress exercise its power to block foreign acquisitions only when it has a truly detrimental effect on national security. Anything short of this will be perceived by the international community as an arbitrary interference with global trade. These interferences should be carefully considered due to the potential for economic retaliation by other nations. For example, it is not clear how China will choose to respond to the CNOOC-Unocal event, but it is most likely going to hamper the ability of any U.S. company seeking to acquire a Chinese energy firm in the future. Why should the Chinese government allow a U.S. company to do what the U.S. government did not allow the Chinese to do? It is also possible that this impediment to foreign acquisition will play itself out in other, non-energy related sectors of the Chinese economy.

The broadening of these national security exceptions is not limited to China either. There are already some indications that CFIUS is applying FINSA to a much broader range of industries than ever before: "CFIUS is treating acquisitions of infrastructure, such as oil refineries and toll roads, which would

193. Nathan Bush, Anticipating Chinese Antitrust Policy, 35 CHINA BuS. REv. 1, 2008 WLNR 1296406, at 1.

194. Id. at 5.

195. Tom Fenton, The Dollar's Decline Does Matter, CBS NEws, Dec. 6, 2004 http://www.cbsnews.com/stories/2004/12/06/opinion/fenton/main659179.shtml.

196. Weak Dollar Draws Investors, BaltimORE SUN, Jan. 8, 2008, available at http://www.baltimoresun.com/business/investing/bal-bz.buyouts08jan08,0,6765543.story. 
not have even been notified for screening in the past, as having national security importance." 197 If the application continues to broaden into other nonsecurity related industries, there will almost certainly be a backlash from other nations, including China. Therefore, it is extremely important that Congress, CFIUS, and the U.S. government apply FINSA carefully. An increase in governmental interference with the global economy in the name of "national security" will ultimately make it more difficult for domestic companies to acquire foreign assets and enter new markets.

It is possible for Article 31 of the new Chinese antitrust law to be integrated into the global economy quickly and seamlessly. For this to occur, the Chinese government will need to define and implement the law in accordance with international standards. Furthermore, foreign investors need to determine whether their proposed merger or acquisition could have an adverse affect on China's national security in light of recent examples from around the world. Finally, in order to ensure that Article 31 is not arbitrarily applied to U.S. companies, the U.S. government needs to carefully apply its own foreign investment regulations so as to keep retaliation by the Chinese government to a minimum.

\section{CONCLUSION}

Article 31 of the Chinese antitrust law is not something to be feared by the international business community. On its face, it may look like an attempt by the NPC to legalize economic protectionism in the burgeoning Chinese economy. However, when compared to international standards on the subject, it does not deviate from the norm. Throughout the world, economic isolationism is accepted in small amounts so as to protect the national security interests of the nation. Most major international trade agreements allow for these national security exceptions, and many of the largest economies in the global market take advantage of these exceptions to protect certain "crown jewel" industries. This may not be the most advantageous model for the developing global economy, but nevertheless it is the international standard and should be applied equally to all nations. Therefore, Article 31 , as it is written, is in accordance with global standards and should be viewed as such, until the Chinese government gives the international community reason to believe otherwise. 
